\title{
Critical Success Factor of Graduate Employability Programs
}

\author{
B. Aida, A. W. Norailis, and R. Rozaini
}

\begin{abstract}
The realm of emerging globalization urges the competitiveness in all aspects, including the education world. Whilst most universities focus on producing graduates to fill the labour market, a number of such graduates is equipping themselves with soft skills via employability program. Emphasis is on the management of their relationships with work and with learning. This requires skills such as negotiating, action planning and networking, added to qualities of self-awareness and confidence. According to Ranjit Malhi (2012) degree is no guarantee of a job and now employers are now looking for various soft skills in graduates, besides technical competence and work experience. For such reason, this paper attempts to examine whether the contents or the context of Graduates Employability Program has been successful in boosting employment potential of graduates in Malaysia. The case study in Department of Labour showed the significant results that one of the goals of the employability programs which is to enhance the marketability of respondent in the labour market was successful $(M=3.10$, S.D. $=1.266)$, contents of the programs objectives were manageable $(M=2.97$; S.D. $=1.406)$ and clear $(M=2.95 ; S . D .=1.243)$ and are relevant (M=2.94; S.D.=1.085) which form the basis to enhance the graduates communication skill. This result has clearly shown that the module and components of the program are the most important for graduate employability. In conclusion, the current graduate employability program should focus on the context of the program.
\end{abstract}

Index Terms-Contents, contexts, employability skills and graduates employability.

\section{INTRODUCTION}

Graduates employability remains as national issues due to the increasing number of graduates produced by higher education institutions each year. For many years, employers have been concerned about the ability of graduates to work in a modern organization. This concern pre-dates the recent rapid expansion in higher education and the concomitant concerns, expressed in some quarters, about the standards and abilities of graduates in the new globalization.

The real issue in Malaysia is not whether graduates are better or worse in absolute terms than they were in previous decades. Rather it is the integration of new graduates as employees into an organization and the speed at which they can contribute effectively that has become a critical success factor. The factor is vital to suit the labour, capital, natural resources and entrepreneurship issues that contribute and influence economic growth in the country. As such, these

Manuscript received February 14, 2014; revised April 24, 2014.

The authors are with the Universiti Sains Islam Malaysia (e-mail: aidanazri2002@yahoo.com). components have been taken into consideration when designing curricula the graduates employability program mained by the Department of Labour of Malaysia. Since the graduates employability program introduced in 2010 as part of Malaysia's aspiration in year 2020, seven programs were developed and had successfully produced quality employees to match the employers' need. The program being a continuum task involving three parties: the employer or industry offering the placement, training providers as the facilitators and the unemployed graduates as participants of the program for a duration between two months to two years. Evaluating the program is a critical part in this process particularly in identifying the success factor to further be enhanced.

\section{LITERATURE REVIEW}

In the labour market, employers look for a range of skills in graduate applicants, many of which are common to a number of different career areas. Most frequently mentioned are communication, team working, leadership, initiative, problem-solving, flexibility and enthusiasm. Many skills overlap with one another which is also known as context per se. Leadership, for example, encompasses a number of other skills including cooperating with others, planning and organising, making decisions and verbal communication. Verbal communication itself involves various means of communication, skills for presentation particularly being in executive tiers. The challenge in the employability program is how to inspire and bridge the gap between the practical and theoretical with a participant graduate who really just wants to learn operational and practical skills to prepare for work.

\section{A. Employability Skills}

The two greatest concerns of employers today are finding talent workers and training them. The difference between the skills needed on the job and those possessed by employers is real concern to the top management and human resource looking to hire competent employees. Employability skills are defined as skills required not only to gain employment, but also to progress within an enterprise so as to achieve one's potential and contribute successfully to enterprise strategic directions. Employers need reliable, responsible workers who can solve problems and who have the social skills and attitudes to work together with other workers [1]. Creativity, once a trait avoided by employers who used a cookie cutter system, is now prized among employers who are trying to create the empowered, high performance workforce needed for competitiveness in today's marketplace. Employees with these skills are in demand and are considered valuable human capital assets to companies 
[2]. The three skill sets are typically broken down into more detailed skill sets in Table I.

TABLE I: BASIC EMPLOYABILITY SKILLS

\begin{tabular}{|c|c|c|c|}
\hline $\begin{array}{l}\text { Basic Academic } \\
\text { Skills }\end{array}$ & $\begin{array}{l}\text { Higher Order } \\
\text { Thinking } \\
\text { Skills }\end{array}$ & $\begin{array}{l}\text { Personal } \\
\text { Qualities }\end{array}$ & \\
\hline Reading & Learning & Responsibility & Team work \\
\hline Writing & Reasoning & Self Confidence & $\begin{array}{l}\text { Punctuality and } \\
\text { Efficiency }\end{array}$ \\
\hline Science & Creativity & Self-Control & Self-Directed \\
\hline Mathematic & $\begin{array}{l}\text { Decision } \\
\text { Makers }\end{array}$ & Social Skills & Good Attitude \\
\hline $\begin{array}{l}\text { Oral } \\
\text { Communication }\end{array}$ & $\begin{array}{l}\text { Problem } \\
\text { Solving }\end{array}$ & Honesty & Well Groom \\
\hline \multirow[t]{2}{*}{ Listening } & & Integrity & Cooperative \\
\hline & & $\begin{array}{l}\text { Adaptable and } \\
\text { Flexibility }\end{array}$ & $\begin{array}{l}\text { Self-Motivated and } \\
\text { Self-Management }\end{array}$ \\
\hline
\end{tabular}

Enhancing employability skills of the graduates is not a new topic and policy makers are still making plans to increase graduate skills to meet the need of the current workforce. As part of the graduate utilization and retention agendas, the vision for the graduate enterprise strategy is to develop graduates who can help create a competitive, dynamic and knowledge based economy. The institutions of higher learning are one of key player in enhancing employability and their responsibility is to identify how they can enhance skills of their students. The strategy, however, encourages all graduates to become more entrepreneurial because the skills and experience developed along the way will produce more enterprising graduates whose added value skills are applicable to any employment situation or occupational sector.

\section{B. Employers Expectation}

In the 21 st century the most significant challenge for graduates will be manage their relationships with work and learning. In the employers' perspective, whether in small, medium and large enterprises have identified the same critical mix of skills as being relevant to the employability and ongoing employment of individuals. It requires skills such as negotiating, action planning and networking, added to qualities of self-awareness and confidence. These are the skills required to be "self-reliant" in career and personal development; skills to manage processes rather than functional skills [3]. In developing these skills there is a part to be played by students, higher education, employers and policymakers. Enhancing graduate employability skills is considered as an important task within the university community in any country. Employability program instituted by several agencies in Malaysia builds around individual factors, personal circumstances and external factors, which acknowledges the importance of both supply-and demand-side factors [4].

TABLE II: KEY GENERIC SKILLS FRAMEWORK

\begin{tabular}{|c|c|c|}
\hline Skills area & Skills claims & Possible evidence \\
\hline Communication & $\begin{array}{l}\text { Organizing and expressing ideas concisely. } \\
\text { Speaking clearly and directly to individuals or groups. } \\
\text { Being proficient in other languages. }\end{array}$ & $\begin{array}{l}\text { Writing assignments and reports. } \\
\text { Presenting and participating in class discussions. } \\
\text { Using customer service skills. }\end{array}$ \\
\hline Teamwork & $\begin{array}{l}\text { Team work in a team to achieve a common goal. } \\
\text { Sharing information, supporting and empowering other team } \\
\text { members. } \\
\text { Responding constructively to the opinions of others. }\end{array}$ & $\begin{array}{l}\text { Working on group assignments at university. } \\
\text { Being involved in a student society, sports team } \\
\text { or organization. } \\
\text { Working in a team in employment. }\end{array}$ \\
\hline Problem solving & $\begin{array}{l}\text { Researching and selecting relevant information to solve a problem. } \\
\text { Analyzing issues for underlying causes, assessing options, } \\
\text { proposing solutions. } \\
\text { Thinking sequentially, critiquing and synthesizing information. }\end{array}$ & $\begin{array}{l}\text { Working on assessment exercises such as a } \\
\text { research project. } \\
\text { Participating in work-integrated learning such as } \\
\text { a placement or internship. } \\
\text { Working within a customer service environment } \\
\text { and dealing with complaints. }\end{array}$ \\
\hline $\begin{array}{l}\text { Initiative and } \\
\text { enterprise }\end{array}$ & $\begin{array}{l}\text { Easily adjusting to new situations. } \\
\text { Mapping out ideas to an action plan. } \\
\text { Identifying innovative options. }\end{array}$ & $\begin{array}{l}\text { Obtaining work placement, vacation employment } \\
\text { or internship } \\
\text { Operating own business. } \\
\text { Innovation in student group, club or team. }\end{array}$ \\
\hline $\begin{array}{l}\text { Planning and } \\
\text { organization }\end{array}$ & $\begin{array}{l}\text { Managing timelines and prioritizing. } \\
\text { Allocating and coordinating tasks for self and others. } \\
\text { Anticipating future needs and forward planning. }\end{array}$ & $\begin{array}{l}\text { Project planning or managing an event. } \\
\text { Arranging study and work commitments to } \\
\text { support you at university. } \\
\text { Organizing,etworking, fundraising, sporting or } \\
\text { social activities. }\end{array}$ \\
\hline Self-management & $\begin{array}{l}\text { Operating independently and taking responsibility for your own } \\
\text { actions. } \\
\text { Being aware of your own strengths and limitations. } \\
\text { Being able to communicate your own ideas. }\end{array}$ & $\begin{array}{l}\text { Acting on feedback and addressing gaps in skills } \\
\text { and knowledge. } \\
\text { Developing a career plan. } \\
\text { Doing work experience through placement, } \\
\text { internship or vacation works. }\end{array}$ \\
\hline Learning & $\begin{array}{l}\text { Putting in time and effort to learn new skills. } \\
\text { Understanding the need for learning to bring about change. } \\
\text { Being adaptable in different learning environments, e.g. class, } \\
\text { online, on the job. }\end{array}$ & $\begin{array}{l}\text { Mentoring or coaching activities. } \\
\text { Participating in an interest group or student } \\
\text { society. } \\
\text { Subscribing to newsletters and updates from } \\
\text { professional associations. }\end{array}$ \\
\hline Technology & $\begin{array}{l}\text { Proficiency in using computers and telecommunications systems. } \\
\text { Understanding current trends and developments Managing } \\
\text { information through technology. }\end{array}$ & $\begin{array}{l}\text { Sourcing information with electronic databases. } \\
\text { Using specialized software packages for } \\
\text { course/occupation. } \\
\text { Managing project timelines with software. }\end{array}$ \\
\hline
\end{tabular}




\section{A. Effective Contents or Contexts}

Nowadays, employers want to recruit multi-skilled (academic Employability strategies should be an integral part of learning and teaching. The employability strategy must be placed at the heart of teaching and learning to ensure that graduates have the opportunity to take the full range of employability skills on board. Most institutions provide for graduate employability within a strategic plan. However, within the institutional strategy there should be a minimum standard of employability support to which institutions commitment. Graduates should be encouraged to take greater responsibility for their employment outcomes on hard and soft skills. These skills are for seeking and keeping employment, have been part of contents of most employability program.

Soft skills refer to "a cluster of personal qualities, habits, attitudes and social graces that make someone a good employee and a compatible co-worker [5]. It is a valued across a variety of jobs, fields and organizations, regardless of position or title. Soft skills are essential for effective performance in a broad range of jobs and are transferable across workplaces. They are considered as key skills identified in conjunction with the personal attributes to make up the Employability Skills Framework in Table II below.

Hard skills are usually related to professional knowledge, tools, or techniques that allow us to work within profession. It is technical or administrative procedures related to an organization's core business. This skill has also been part of the program in preparing the graduates to be marketable.

The framework identifies key essential learning areas which are adopted in the Graduates Employability Program. These are broad, recognizable categories of knowledge and understanding. They constitute a balanced curriculum within which the essential skills, attitudes, and values are developed to $s$ to enable them to reach their full potential and take a full part in society.

\section{MethodolOGY}

This paper employed a self-administered questionnaires to a focus group as survey method, field observations and written documents to illustrate graduates employability program offered by Department of Labour in Malaysia. In order to meet the objectives of the research, the items in the questionnaires were modified and adapted from Magic Bullet Model of Employability [4]. Based on the information gathered, the researcher obtained the responses from ten items pertaining to contents of the program and the generic skills.

This questionnaire was distributed to the respondents at the end of 2012. A total of 145 graduates participated in the programs all over Peninsular Malaysia. 94 completed questionnaires were used in the analysis, which gave a usable rate of 60.7 percent. Table III summarized the background of the respondents. The result was 0.945 from the reliability analysis which signify a strong inter-item consistency and reliability of the items measured. The results of the study could help other related agencies to design better programs in addressing unemployment issue among jobseekers particularly the fresh graduates.

TABLE III: DEMOGRAPHIC PROFILE OF THE RESPONDENTS

\begin{tabular}{lll}
\hline & Characteristics & Percentage \\
\hline Gender & Male/Female & $31.7 / 68.3$ \\
Marital Status & Single/Married/Divorced & $89.7 / 9.0 / 1.4$ \\
Age & $\begin{array}{l}\text { 21-30 /31-40 /41-50 years } \\
\text { old }\end{array}$ & $81.4 / 12.4 / 6.2$ \\
Education & SPM/STPM / Dip / Degree / & $3.4 / 4.8 / 37.9 / 51 / 2.8$ \\
& Master & 57.9 \\
Level & Fresh & 41.4 \\
& Junior & 0.7 \\
\multirow{2}{*}{ Status of Job } & Subordinate & 57.9 \\
& Permanent & 47.6 \\
& Contract & 13.8 \\
\hline
\end{tabular}

\section{FINDINGS AND DisCUSSION}

Table IV presented the sources of the effectiveness of the programs and mean scores. The respondents agreed the subject matter on the employer's expectation is the main subject of their entrance to the employability program. Then, enhancing the employability skills is chosen as the next factor to be gained for employment and to progress within an enterprise. High levels of satisfaction were seen with the relevance and reputation of qualifications achieved by graduates.

TABLE IV: MEAN AND STANDARD DEVIATION FOR CONTENTS OF PROGRAM

\begin{tabular}{|c|c|c|c|}
\hline No. & Items & Mean & $\begin{array}{l}\text { Standard } \\
\text { deviation }\end{array}$ \\
\hline A1 & $\begin{array}{l}\text { The employability programs allows } \\
\text { respondents the opportunity to } \\
\text { integrate classroom objectives and } \\
\text { workplace skills }\end{array}$ & 2.75 & 1.205 \\
\hline A2 & $\begin{array}{l}\text { The employability programs } \\
\text { placements are directly related to the } \\
\text { course of the related class }\end{array}$ & 2.94 & 1.085 \\
\hline A3 & $\begin{array}{l}\text { The employability programs is to } \\
\text { enhance marketability of respondent } \\
\text { in labour market }\end{array}$ & 3.10 & 1.266 \\
\hline A4 & $\begin{array}{l}\text { The contents programs objectives } \\
\text { were clear }\end{array}$ & 2.95 & 1.243 \\
\hline A5 & $\begin{array}{l}\text { The contents programs workload was } \\
\text { manageable }\end{array}$ & 2.97 & 1.406 \\
\hline A6 & $\begin{array}{l}\text { The contents program was well } \\
\text { organized (e.g. timely access to } \\
\text { materials, notification of changes, } \\
\text { etc.) }\end{array}$ & 2.59 & 1.288 \\
\hline A7 & $\begin{array}{l}\text { Notes given were relevant and useful } \\
\text { to achieve learning outcomes }\end{array}$ & 2.58 & 1.553 \\
\hline A8 & $\begin{array}{l}\text { The subject matter presented in the } \\
\text { content programs has increased } \\
\text { knowledge at workplace }\end{array}$ & 2.66 & 0.835 \\
\hline A9 & $\begin{array}{l}\text { The content programs integrates } \\
\text { theoretical basic concepts with } \\
\text { real-world applications }\end{array}$ & 2.87 & 1.973 \\
\hline $\mathrm{A} 10$ & The content programs is updated & 2.66 & 1.3 .51 \\
\hline
\end{tabular}

However, while communication skills were ranked the most important skill in any of employability program, they were only ranked 16th in terms of employer satisfaction. Intellectual abilities such as critical evaluation, internal and external planning across the team and with industry were also adopted in the program. Other, 'softer' generic skills such as work ethic, sensitivity to the nature of the business, 
influencing and leadership were also highlighted in the graduates' personal reflections as they realised their actions were helping the local community thereafter.

It appears that while many graduates hold satisfactory qualifications but they are lacking in the key 'soft' skills and qualities that employers increasingly need in a more customer focused world [6]. It indicates the skills identified as critical to employability are broadly consistent across industry sectors, all are important, though the elements would depend on the industry and workplace context. Accordingly, the program contained syllabus on enhancing creativity and diversity to enable the graduates to adapt with the changes in the workplace. The shape of any organizations or workplace is changing as a result of delivering, out-sourcing and the growth of multi-disciplinary team structures, are examples of changes which affect the ways people work. The pace of change can be hard to judge, but it is clearly faster than any current response. These criteria of matching the employers expectations are regarded as the context that have been identified as success factor in the employability program. Matching the graduates with such context would fulfill the actual lacuna in the labour market and may evade further employment issue of job hopping. The program may further be improved by developing an entrepreneurial activity for instance, which has been adopted by several higher learning institutions in the country as of late. In an increasingly global marketplace, entrepreneurship has a wider responsibility to function in a socially responsible manner and to act as a driver for economic growth, regeneration and employment. As young people are most likely to become active social entrepreneurs, it is suggested that by promoting social enterprise as an alternative business model within the curriculum, levels of social entrepreneurial activity could rise in line with early stage entrepreneurial activity. Evaluating the value and quantitative impact of participation in social enterprise in curricula will be important and it is unknown to what extent this is presently conducted. A module or an actual case studies on providing strategies for assisting real organisations to improve their businesses, may be taken as part of the program.

If an effective job matching activity is added in besides upgrading the contents of the graduates employability program to suit the current employment issues and socio economy of the nation. It is recommended the job match in the existing jobs Malaysia portal could be extended and shared with all private employment agencies and the Government's agencies to become a one stop job centre for Malaysia. Furthermore, it is also proposed that any agency administrating the employability program to include job coaching or apprenticeship program in their effort to place the graduates for the right job. Coaching the graduates to become an enterprising people are vital to the present business growth,

to the delivery of public and third sector services and to the regeneration of communities than condemning the changes in employment policy such as the national minimum wages and reducing the recruitment of the foreign workers into the country.

The future research probably should focus on the potentials of participants of any employability program particularly to transform the participants' perception towards low and unskilled jobs so as fulfilling the aspiration to cater the labour market with such highly educated labour force. If the individual graduates and employer are aware on the opportunities and challenges as well as endeavouring into programmes organized by the Government, the issues on unemployment, unutilised workforce and social illness could be avoided.

As the Department of Labour aims to support the Government's measure to improve the structural weaknesses in the labour market, it is timely to enhance the graduates employability program through the development of emotional intelligence and transferable skills to develop the graduates to become the social entrepreneurs and social sector change agents of the future.

Qualities and competencies learnt from the program undoubtedly make up employability, but a desire to learn, to apply that learning, to adapt and to take advantage of change are value added characteristics needed for a long term employment[7]. These criteria could be developed from time to time by the individual graduates cum employees, which has been an integral context of the program. Once employed, the role of lifelong learning in skill development and response to change, if provided by the employers would be very helpful to the employees and a great human capital investment in the future.

\section{CONCLUSION}

Today's graduates will need to understand that their attitude to work is as important as the work itself. Furthermore, their ability and willingness to undertake professional development and training throughout their working life will be a pre-requisite for lifelong work [8].

This paper seems to verify that the graduates employability program should emphasize on the contextual approach as academics alone is not the main factor of one to be employed. The lack of soft skills and durability besides the attitudinal selective jobs tend to turndown employers of taking the graduates into their workplace. Thus, the graduate employability program has become an increasingly important platform to produce quality employees for the competitive labour market.

\section{REFERENCES}

[1] D. D. Curtis, Employability Skills for the Future, Report for Australian Chamber of Commerce and Industry, pp. 1-6, 2002.

[2] P. Burden and C. M. Avinia. (1998). Employers' need and graduate skills. http://www.surrey.ac.uk/skills/reports/graduate

[3] P. J. Robinson. (2000). What Are Employability Skills. http://stlwebdev.us/careerdev/documents/Employability-Skills.pdf

[4] L. Harvey, "Defining and measuring employability," Quality in Higher Education, vol. 7, no. 2, pp. 97-109, 2010.

[5] J. M. Yunos, W. Mohd, R. W. Ahmad, N. Kaprawi, and W. Razzaly, "Technical \& vocational education \& training (TVET) from Malaysian Perspective," presented at 2nd. International TV-TVET-Asia-Link Project Meeting, VEDC Malang, Indonesia 27th August - 2nd. September, 2006.

[6] K. Lorenz. (2014). What are soft skills. Career Builder http://jobs.aol.com/articles/2009/01/26/top-10-soft-skills-for-job-hunt ers/

[7] L. A. Shafie and S. Nayan, "Employability awareness among Malaysian undergraduates," International Journal of Business and Management, vol. 5, no. 8, pp. 119-123, 2010. 
[8] A. Zaharim, M. Z. Omar, Y. M. Yusoff et al., "Practical framework of employability skills for engineering graduate in Malaysia," in Proc. the IEEE Conference on Education Engineering, 2010, pp. 921-927.

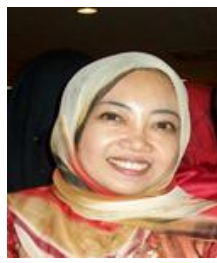

B. Aida is an industrial relation officer in ministry of human resources (MOHR), Malaysia. She has gained vast knowledge and experience in employment matters and human resources issues during her 12 precious years serving in Labour Department, Putrajaya and at present in National Wages Consultative Council, as secretariat formulating the national minimum wages of private sector. She was formerly an advocate and solicitor and a member of Malaysian Bar. Born in October, 1973 in Kuala Lumpur, she completed her first degree in LL.B (Hons) International Islamic University Malaysia in 1996. Completed her Master in Human Resources Management, Universiti Utara Malaysia in 2008, Currently pursuing her $\mathrm{PhD}$ at Universiti Sains Islam Malaysia.

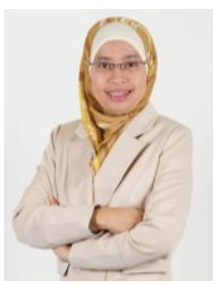

A. W. Norailis is a senior lecturer in the Faculty of Economics and Muamalat, Universiti Sains Islam Malaysia (USIM). She is a member of Malaysian Muamalat association (MMA) and The Malaysian consumer and family economics association (MACFEA). She attained her first degree in Industrial Economics in 2000 and master in science (productivity and quality enhancement) in the following year from Universiti Kebangsaan Malaysia. In the middle of 2009, she had been awarded PhD from the University of Stirling, Scotland. She joined SME Corporation Malaysia for three months in 2012 through
USIM academic staff attachment program to gain industrial experiences and strengthen the networking with practitioners in small and medium enterprises (SMEs). She has published two case studies on umrah management and organizational issues in "Integrated Muamalat Case Study" published by the Penerbit Universiti Sains Islam Malaysia. Currently, she is actively involves in research on benchmarking, supply chain and umrah management as well as in activities organized by Malaysia productivity corporation (MPC) and SME corporation Malaysia (SME Corp).

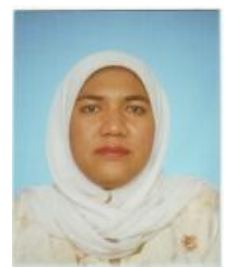

R. Rozaini started career as executive to senior in one of the insurance industry in Malaysia. She was born on September 2, 1972 in Kelantan. She attained her first degree in public management in 2005 and master in human resources management 2008 from University Utara Malaysia, Malaysia and currently pursuing her $\mathrm{PhD}$ at University Sains Islam Malaysia (USIM). In the past 16 years she has gained vast knowledge and experiences in insurance industry. She has taught of insurance courses for tertiary institutions in Malaysia. Her research supervisions have been in the areas of insurance in Malaysia. In 2013 she has published one case study in "Integrated Muamalat Case Study" published by the Penerbit Universiti Sains Islam Malaysia (USIM). She is actively involves in research papers in internationally well-known refereed journals and conferences. 